\title{
Effectiveness and Application of Assisted Technology in Italian Special Psycho- Education: A Pilot Study
}

\author{
Giusi Antonia TOTO and Pierpaolo LIMONE
}

University of Foggia, Foggia, Italy

Correspondence should be addressed to: Giusi Antonia TOTO; giusy.toto@unifg.it

Received date: 21 April 2020; Accepted date:27 June 2020; Published date: 20 July 2020

Academic Editor: Sebastian Kell

Copyright (C) 2020. Giusi Antonia TOTO and Pierpaolo LIMONE. Distributed under Creative Commons Attribution 4.0 International CC-BY 4.0

\begin{abstract}
Assistive technology allows to remove a number of obstacles to the complex psycho-educational needs of students with disabilities. The purpose of this research is to collect information on the knowledge, skills and perceptions of assistive technology among teachers in the context of Foggia, as a pilot study for a wider national reflection. The data were collected through consultation of official databases and through a survey, submitting to a sample of teachers a questionnaire used in an international context, translated in Italian. The results suggested that teachers do not have an adequate level of knowledge and skills in the use of assistive technology and require pre-service and in-service training to increase their general knowledge on assistive technology implementation and to plan effective actions for students with disabilities.
\end{abstract}

Keywords: Assistive Technology, Special Needs, Disabilities, Learning Environments.

\section{Introduction}

The didactic planning of artefacts and educational environments to return meaningful learning to any student must propose solutions that can be used by everyone and to their full potential (Burgstahler, 2012). Assistive technology (AT) means any product, virtual or real, capable of increasing, maintaining or

Cite this Article as: Giusi Antonia TOTO and Pierpaolo LIMONE (2020)," Effectiveness and Application of Assisted Technology in Italian Special Psycho-Education: A Pilot Study", Journal of e-Learning and Higher Education, Vol. 2020 (2020), Article ID 177729, DOI: 10.5171/2020.177729 
improving the functional skills of people with disabilities (Young, 2013). In fact, thanks to its primeval innovative nature, assistive technology has spread to the most disparate sectors of human life, not least in training. The use at school, therefore, of technological devices to support students with special needs in learning is a vexata quaestio, which clashes with objective environmental deficiencies and ambiguous cultural heritage, reinforced by actions of resistance to the use of technologies at school (Limone \& Toto, 2020). The realization of a truly inclusive education concerns not only the design of personalized didactic interventions, but also through the development of facilitating learning environments. The definition of effective learning present in psychology is affected by the classical theory of Vygotskij (1995), reinterpreted in the light of recent research by Booth \& Ainscow (2011), must leverage the social dimension of learning through active and participatory teaching proposals. Continuing to enhance the value of participation in training processes rather than inclusion, as stated in the International
Statistical Classification of Diseases and Related Health Problems 11th revision (ICD11), all'International Classification of Health Interventions (ICHI), (WHO, 2018). Participation according to this theoretical model is expressed in the social and active dimension of learning. In the contemporary context, technologies are the subject of study of the psycho-pedagogy of special needs to favor the processes of social and educational inclusion.

Unlike the use of assistive technologies in the rehabilitation and medical field, more simply accepted for their main support for motor function, ATs in the school context as a support to cognitive activities still laboriously have free diffusion, although they are encouraged by a vast pedagogical literature (Bonwell \& Eison, 1991). Assistive technology provides students with disabilities the same opportunities to participate in active environments with predictive activities aligned with their abilities.

Table 1: Main technological tools for school disability support.

\begin{tabular}{|c|c|c|c|}
\hline Disability & Motor & Visual & Auditory \\
\hline $\begin{array}{l}\text { Tools } \\
\text { found in } \\
\text { schools }\end{array}$ & $\begin{array}{l}\text { - Keyboards (mini, } \\
\text { expanded, virtual, } \\
\text { etc.); } \\
\text { - Pointing systems } \\
\text { (trackball, } \\
\text { joystick, touch } \\
\text { pad, touch, } \\
\text { screen); systems, } \\
\text { - Scan syste } \\
\text { voice commands, } \\
\text { sensors. }\end{array}$ & $\begin{array}{ll}\text { - } & \text { Adaptation of texts; } \\
\text { - } & \text { Sign recognition } \\
& \text { software; } \\
\text { - } & \text { LIM } \\
\text { - } & \text { Touch monitor } \\
\text { - } & \text { Voice / written } \\
& \text { conversion } \\
& \text { software }\end{array}$ & $\begin{array}{ll}\text { - } & \text { Speech synthesis; } \\
\text { - } & \text { Screen reader; } \\
\text { - } & \text { Display and braille } \\
& \text { printer; } \\
\text { - } & \text { Portable braille } \\
& \text { devices } \\
\text { - } & \text { Enlargers and } \\
& \text { video ingraditors; } \\
\text { - } & \text { Scanner and OCR } \\
& \text { system; } \\
\text { - } & \text { Digital audiobooks } \\
& \text { and book readers } \\
\end{array}$ \\
\hline
\end{tabular}

The technology for disability at school substantially consists of a PC equipped with a suite of software and specific platforms for the different special needs (a separate discussion must be made for visual disabilities where the ATs have reached a high degree of training in training contexts specialization). For example, even in the presence of severe motor disabilities, the use of keyboards, pointing systems, touch screens or voice commands allows to carry out didactic tasks (Limone \& Toto, 2019). The software for hearing impairments is in a phase of rapid experimentation, in which the 
written text, while maintaining the role of the main access channel to external communication, is substantiated in a decrypted text and translated into LIS language through digital devices (van Niekerk, et al., 2018). The greatest results in terms of technology applied to special needs occurred for visual impairments; in addition to the aforementioned speech synthesis systems and screen readers, the research was directed towards specific technological artefacts and software offering a support during the learning process, such as braille displays and printers, video magnifiers, OCR scans and digital audiobooks. The introduction of compensatory tools into the classroom, including information technology and alternative learning methodologies for DSAs, has given a strong boost to the search for applications also in this area.

\section{State of art}

The international debate has been asking for more than twenty years on the effective presence of TA in schools and what is the current level of knowledge and skills of teachers in the use of assistive technology (Alkahtani, 2013), research questions that have also addressed the present study. Another dimension investigated is the teachers' perception of the use of assistive technology with their students. For this purpose, we selected and compared for their possible use in the Italian context two (questionnaires) surveys used in the international research context. The first one was drawn up by Chmiliar (2007), structured in its very complex final version on personal information, followed by 13 items on training on the subject of TA and on the type of training followed, a question that asks participants to evaluate their TA skills and knowledge, (an open question asking participants to identify assistive technology funders, not relevant to this study), 12 questions about the use and satisfaction of using assistive technology, a list of 12 options to evaluate the barriers and obstacles to learning and a list of 10 items to evaluate the importance in the provision of services and in the financing of TA and, finally, numerous opportunities to provide comments. The study also replicated in other contexts (Kutlu et al., 2018) produced the following results: in two research studies conducted by the team led by prof. Kutlu $(2007,2018)$, the support teachers involved (248 in the American context in the first study, 211 in Turkey in the second) said they had not received in-service training on assistive technology and that they did not feel sufficiently adequate in the use of assistive technology, neither software, nor hardware. The degree of dissatisfaction widened $50 \%$ of the participants in the research in relation to the contemporary skills and knowledge of technological tools for special needs. This result, according to the authors, is related to the effective availability of equipment in the schools investigated, therefore the dissatisfaction depended on the environmental deficiency. Finally, in both studies, the teachers indicated innovative teaching strategies as the most important tools available to them in school educational practice.

The second questionnaire developed by Alkahtani (2013) was designed by integrating quantitative research strategies with qualitative interviews, according to the models of Fowler $(2008)$ and Creswell (2008). It is, actually, the screening of quantitative research that naturally selects subjects to deepen the topics of qualitative interviews. The survey respects the guidelines of the Consortium of Quality Indicators for Assistive Technology (QIAT) and consists of a first part structured in six items for the collection of personal information and a second part of 13 items designed to evaluate the use and level of knowledge of assistive technology of by the teachers. Finally, in the first version there is a last question requesting availability to undergo a 15-minute telephone interview on the same issues. 


\section{Methodology}

The investigation, in this first pilot phase, did not map all the 427 support teachers in the province of Foggia, however the questionnaire was administered to a representative sample of 81 referents for the disability of local schools. The data presented in conclusion relate to this second sample interviewed. The sample consisted of 127 teachers (referents and support teacher) (14 males, 113 females; Mage $=44,85, \mathrm{SD}=6,33$ ). The questionnaire was translated from

\section{Parte I: Informazioni demografiche}

Si prega di completare le informazioni su di te.

1 - Qual è la tua età?

----- Meno di 30 anni.

----- 30-40

----- 41-50

----- 51-60

----- Più di 60 anni.

2 - Qual è il tuo genere?

---- Maschio.

---- Femmina.

3 - Qual è il più alto livello di istruzione che hai completato?

----- Laurea triennale.

----- Master.

---- Dottorato.

----- Altro (prego specificare).

4 - Qual è la tua posizione lavorativa?

----- Insegnante Curriculare.

----- Insegnante di Sostegno.

----- Altro (prego specificare).

5 - Quale degli aggettivi proposti descrive meglio la posizione della scuola in cui insegni?

----- Rurale.

---- suburbano.

---- Urbano.

6 - Quanti anni di esperienza hai nell'istruzione?

----- Meno di un anno.

---- 1-2 anni.

---- 3-5 anni.

----- 6-10 anni.

----- Più di 11 anni.

\section{Parte II: Uso e conoscenza della tecnologia assistiva}

Si noti che questo questionario si basa sulla definizione IDEIA 2004 della tecnologia assistiva che include dispositivi high-tech (cioè dispositivi di comunicazione alternativi) e include anche 
elementi che in genere non possono essere considerati "tecnologici" (vale a dire impugnature a matita).

1 - Hai mai usato o richiesto una valutazione della tecnologia assistiva per uno studente?

----- Sì

---- No

2 - Le esigenze di tecnologia assistiva sono prese in considerazione dal team GLH della tua scuola?

----- Sì

---- No

3 - Gli studenti della tua scuola hanno accesso alla tecnologia assistiva?

----- Sì

---- No

4 - Quali tipi di tecnologie assistive sono disponibili nella tua scuola (scegli tutte le risposte pertinenti)?

----- Dispositivi a bassa tecnologia (penna luminosa per migliorare area di scrittura, pinze, scrivanie adattive).

----- Dispositivi di media tecnologia (tasti appiccicosi, penna Iris, tastiera portatile Neo 2)

---- Dispositivi high-tech (apparecchi acustici e / o di ascolto assistito, programmi di predizione di parole, alternative da tastiera).

5 - Sei pronto a fornire servizi di tecnologia assistiva ai tuoi studenti?

----- Per niente preparato.

----- Scarsamente preparato.

----- Piuttosto preparato.

----- Preparati adeguatamente.

----- Estremamente ben preparato.

6 - Stima il tuo livello di conoscenza della tecnologia assistiva.

---- Nessuna conoscenza.

---- Poca conoscenza.

---- Qualche conoscenza.

---- Buona conoscenza.

----- Ampia conoscenza.

7 - Stima il numero di corsi universitari o di livello universitario che hai svolto in cui la tecnologia assistiva è stata trattata nel dettaglio (cioè più di una sessione di classe).

---- Nessuno

$----1-2$

$----3-4$

---- 5 o più.

8 - Stima il numero di workshop o di formazione in servizio riguardanti specificamente la tecnologia assistiva che hai frequentato nella tua carriera.

----- Nessuno

$----1-2$

$----3-4$

---- 5 o più.

9 - Sei interessato a ricevere formazione e sviluppo professionale nel settore della tecnologia assistiva?

----- Sì, sono molto interessato.

----- Non lo so, ci penserò.

----- No, non mi interessa per niente.

10 - Pensando al tuo stile di apprendimento e alle tue esigenze, indica il tuo metodo preferito per l'apprendimento dell'assistenza tecnologica (scegli tutte le risposte pertinenti).

----- Istruzioni individualizzate individuali. 
----- Le istruzioni pratiche nell'impostazione di gruppo.

----- Frequentare workshop o sessioni di conferenze.

----- Corsi formalizzati (vale a dire per il credito universitario).

---- Altro (prego specificare).

11 - Lo studente deve apprendere senza l'uso tecnologia assistiva, dato che il suo utilizzo ne

influenzerebbe negativamente lo sviluppo delle abilità?

----- Fortemente in disaccordo.

----- Disaccordo.

----- Neutro.

----- Essere d'accordo.

----- Fortemente d'accordo.

12 - Sei d'accordo che la tecnologia assistiva consente agli studenti di accedere alle attività del loro curriculum?

---- Fortemente in disaccordo.

----- Disaccordo.

----- Neutro.

----- Essere d'accordo.

----- Fortemente d'accordo.

13 - Sei d'accordo che l'utilizzo della tecnologia assistiva richiede così tanto tempo extra e rallenta il ritmo di apprendimento per la classe.

----- Fortemente in disaccordo.

---- Disaccordo.

----- Neutro.

----- Essere d'accordo.

----- Fortemente d'accordo.

Participants voluntarily completed a questionnaire designed to investigate the use and level of knowledge of assistive technology of by the teachers. Questionnaire completion took place at the school and outside the lessons. Anonymity and confidentiality have been clearly underlined through verbal and written instructions. Informed consent was obtained before the participants provided socio-demographic information and completed the scales.

\section{Results and Discussion}

The analysis carried out on data relating to 855 students with disabilities present in attending the schools of Foggia in the school year of 2018-19 (staff of law and derogations) proposes a magmatic situation (Tab. 2).

Table 2 - Distribution of pupils in schools in the province of Foggia.

\begin{tabular}{|l|l|l|l|l|}
\hline & Cognitive & Motor & Visual & Auditory \\
\hline & 696 & 80 & 49 & 30 \\
\hline Percentage & $81 \%$ & $9 \%$ & $5.5 \%$ & $3.5 \%$ \\
\hline
\end{tabular}

For both pupils with motor and with cognitive disabilities, the $\mathrm{PC}$ is the main support tool for those in difficulty; the major drawbacks encountered by the teachers are 
the slowness of didactic interventions conducted in the classroom and the easy distractibility of the group with respect to individual work. The didactic emergency of multimodal instrumentation for blind people (Tab. 1) has the advantage in the perception of the curricular teacher of not needing intermediaries and of involving the pupil in shared activities for the plasticity of the documents produced. Furthermore, the same type of advantage is found in pupils with hearing disabilities. Finally, almost all of the teachers involved manifest the pedagogical emergency of in-service training through courses for the use of AT in the school. With regard to the demographic data collected, it can be seen that in the geographical area concerned the support teachers are in urban areas with a higher age group (41-50 years) $43 \%$ of the sample. In contrast, relatively younger teachers (30-40 years old) work in rural areas for $39 \%$. In the context of southern Italy, there are also gender differences in the workplace, $89 \%$ of respondents are female (which approaches $100 \%$ in lower education levels).

\section{Conclusions}

The educational success of pupils with disabilities is strengthened through effective and proper use of assistive technologies by teachers (Caldin, 2006). The international literature (Laughlin et al., 2018) describes the implementation of skills and knowledge related to rapidly evolving $\mathrm{TA}$ as essential for the professional development of teachers, curricular and support. The results of this study confirm the research conducted so far in this area, that describe on the one hand the inadequacy of skills in the use of assistive technology and on the other a need / need for training on these issues. Teachers' perceptions on the usefulness of training for the use of assistive technology in the school influence the frequency with which they are used (Canevaro et al, 2011) and represent another vast field of investigation for future research.
The problem posed in the premises of this study finds a possible solution in a specific course or teaching module to be included in the initial training phase of teachers or in service for teachers already employed. Given the specificity of the subject of the TA, it would be more meaningful and performative to train teachers through simulation mechanisms. The concept of simulation is heavily debated in specialist literature (Kailani et al., 2019) as there are several application models. Compared to the theme of assistive technology, a dynamic simulation model would be more suitable, that is, the educational situation experienced by the user is not static but dynamically feeds back on user behavior, because simulation and behavior evolve together in real time.

The main positive functions of technologies in inclusive education relate, in relation to the specificity of the handicap, to three main purposes: communicative purpose (1) which facilitates access to educational situations, that participation (2) at a distance, an increasingly used method in all emergency situations and personalization (3) which simplifies the cognitive aspects of knowledge. The technology facilitates the compensation mechanism. With this term we mean the strategy of adaptation to the context activated by technologies. The dialectical mechanics of compensation / insufficiency directs the deficient subject towards two antinomic pathways, one propulsive and the other pathological, both triggered by the context, which restructures all adaptive functions, structures and substitute processes, and creates conditions of proximal development (Vygotsky, 1995). In this perspective, special teaching becomes an element of extreme experimentalism and innovation (Kling et al., 2010; BouCk, 2011). It is precisely the situations of emergency and disadvantage that stimulate the professional growth of educators and pushes them to seek new teaching / learning strategies. The school context becomes a privileged environment in which barriers become accessible and peer collaboration develops. Technology, therefore, becomes the 
medium of interaction between the inside of the school and the outside of the sociocultural context of the subject (Toto, 2017; 2018). To develop autonomy and equal opportunities in children with disadvantages, a planned and systemic use of technology is also necessary. The didactic design rethought in this perspective allows the acquisition of life skills.

\section{Acknowledgement}

Thanks to prof. Keetam D. F. Alkahtani, Dept. of Special Education, King Saud University, for giving permission (authorizations) to translate and use the survey he developed, in this and future studies. We also thank the USP of Foggia for the context data, which can be consulted at the link www.ustfoggia.it

\section{References}

- Alkahtani, K. D. (2013). Teachers' knowledge and use of assistive technology for students with special educational needs. Journal of Studies in Education, 3(2), 65-86.

- Bonwell, C. C., \& Eison, J. A. (1991). Active Learning: Creating Excitement in the Classroom. 1991 ASHE-ERIC Higher Education Reports. Washington, DC: ERIC Clearinghouse on Higher Education, The George Washington University.

- BouCk, E. C. (2011). Teachers' initial and sustained use of an instructional assistive technology tool: Exploring the mitigating factors. Journal of Educational Multimedia and Hypermedia, 20(3), 247266. Kling, A., Campbell, P. H., \& Wilcox, J. (2010). Young children with physical disabilities: Caregiver perspectives about assistive technology. Infants \& Young Children, 23(3), 169-183.

- Burgstahler, S. (2012). Equal access: Universal design of instruction. Seattle: DO-IT, University of Washington. Available: www.uw.edu/doit/equalaccess-universal-design-instruction (March 24, 2019). Young, G. (2013). Assistive technology for students with learning disabilities: perceptions of students and their parents. TechnologyMediated Learning, 77-83.

- Caldin, R. (Ed.). (2006). Percorsi educativi nella disabilità visiva: identità, famiglia e integrazione scolastica e sociale. Trento: Edizioni Erickson.

- Canevaro, A., d'Alonzo, L., Ianes, D., \& Caldin, R. (2011). L'integrazione scolastica nella percezione degli insegnanti. Trento: Edizioni Erickson.

- Chmiliar, L. (2007). Perspectives on Assistive Technology: What Teachers, Health Professionals, and Speech and Language Pathologists Have to Say. Developmental Disabilities Bulletin, 35, 117.

- Churchman, C.W. (1971). The Design of Inquiring System. New York: Basic Books.

- Creswell, J. (2008). Educational research: Planning, conducting, and evaluating quantitative and qualitative research. Upper Saddle River, NJ: Merrill Prentice Hall.

- Fowler, F. (2008). Survey research methods. (4th ed.) Thousand Oaks, CA: Sage Publications.

- Ivory, J., \& Gean, S. (1991). A paradigmatic Analysis of Contemporary IT development. European Journal of IT, 1(4), 249-272.

- Kailani, S., Newton, R., \& Pedersen, S. (2019, June). Game-Based Learning and Problem-solving Skills: A Systematic Review of the Literature. In EdMedia+ Innovate Learning (pp. 1109-1119). Waynesville, NC: Association for the Advancement of Computing in Education (AACE).

- Kutlu M., Schreglmann S., \& Cinisli N. A., (2018). The Opinions of Special Education Teachers on the Use of Assistive Technologies in Special Education. YYÜ Eğitim Fakültesi Dergisi (YYU Journal of Education Faculty), 15(1), 1540-1569.

- Kutlu, M., Balci, S., \& Yilmaz, M. (2007). İletişim Becerileri Eğitiminin Öğrencilerin Kendini Ayarlama ve İyimserlik Düzeylerine Etkisi. Eurasian 
Journal of Educational Research, (27), 14.

- Laughlin, M. K., Murata, N. M., Gonnelli, M., \& Larranaga, J. (2018). Assistive Technology: What Physical Educators Need to Know. Journal of Physical Education, Recreation \& Dance, 89(3), 3845.

- Limone, P., \& Toto, G. A. (2020). Peer Learning and Peer Assessment to Enhance Participation in Online Courses: A Brief Theoretical Overview of Research Findings and Strategies. In E. Podovšovnik (Ed.), Examining the Roles of Teachers and Students in Mastering New Technologies (pp. 1-26). Hershey, PA: IGI Global. doi:10.4018/978-1-79982104-5.ch001

- Presser, S., Couper, M. P., Lessler, J. T., Martin, E., Martin, J., Rothgeb, J. M., \& Singer, E. (2004). Methods for testing and evaluating survey questions. Public opinion quarterly, 68(1), 109-130.

- Toto G. A., \& Limone P. (2019). Research on a massive open online course (MOOC): a Rapid Evidence Assessment of online courses in physical education and sport. Journal of Physical Education and Sport, 19, 2328-2333.
- Toto, G.A. (2017). The influences of musical learning on psycho-physical development, intelligence and technology. The online journal of educational technology, 16(1), 801-807.

- Toto, G.A. (2018). From Educational Contexts to Addictions: the Role of Technology in Teaching Methodologies and in Prevention as an Educational Function. Journal of e-Learning and Knowledge Society, 14(2), 203-212.

- $\quad$ van Niekerk, K., Dada, S., Tönsing, K., \& Boshoff, K. (2018). Factors perceived by rehabilitation professionals to influence the provision of assistive technology to children: a systematic review. Physical \& occupational therapy in pediatrics, 38(2), 168-189.

- Vygotsky, L. S. (1995). Problemy Defectologii [Problems of Defectology] Moscow: Prosvecshenie Press.

- WHO, (2018).International Statistical Classification of Diseases and Related Health Problems 11th revision (ICD-11), In International Classification of Health Interventions (ICHI). 